Annales Missiologici Posnanienses t. 19 (2014), s. 167-179

DOI: $10.14746 / \mathrm{amp} .2014 .19 .7$

MAREK KRÓL

Wydział Teologiczny Uniwersytetu Kardynała Stefana Wyszyńskiego, Warszawa

\title{
Udział Kościoła katolickiego we wprowadzaniu pokoju pomiędzy plemionami prowincji Southern Highlands w diecezji Mendi w Papui-Nowej Gwinei
}

Diecezja Mendi obejmuje obszar pokrywający prowincję Southern Highlands. Leży na terenie Gór Centralnych, które charakteryzują się nie tylko wysokimi szczytami, ale również długimi dolinami poprzecinanymi rzekami i strumieniami. Takie ukształtowanie powierzchni wpływa na zróżnicowanie klimatu, który obejmuje subtropik w rejonach Lake Kutubu, umiarkowany ciepły na obszarze płaskowyżu Tari i w Dolinie Mendi oraz umiarkowany chłodny w okolicach Mount Ialibu i Mount Gilue ${ }^{1}$.

Za początek pracy duszpasterskiej na terenie Southern Highlands przyjmuje się rok 1954 - misjonarze przybyli najpierw do południowowschodniej części obecnej diecezji. Początki działalności misyjnej uzależnione były od decyzji rządu Australii, który sprawował władzę na terenie obecnej Papui-Nowej Gwinei do roku 1975. Southern Highlands, obszar niezbadany i prawie hermetycznie zamknięty przez kilka tysięcy lat, powoli zaczęto otwierać na białych ludzi, którzy jeszcze przed długi czas budzili strach u miejscowej ludności. Kiedy w 1958 r. z części wikariatu apostolskiego Port Moresby utworzono prefekturę apostolską, znaczna część jej terytorium była już otwarta dla przybywających misjonarzy różnych wyznań. W 1965 r. Prefekturę Apostolską Mendi podniesiono do rangi wikariatu apostolskiego, a 15 listopada 1966 r. erygowano tam diecezję Mendi (część terytorium diecezja utraciła w $1971 \mathrm{r}$. na rzecz powołanej właśnie do życia diecezji Kerema $)^{2}$.

${ }^{1}$ Por. S. Tyszkowski, Program rozwoju kultury fizycznej w Papui Nowej Gwinei (Prowincja Southern Highlans) Wedlug wskazań ONZ oraz projektów własnych, Gdańsk 2008, s. 10; por. też: T. Dworecki, Z kraju kamiennej siekiery, Warszawa 1975, s. 410.

${ }^{2}$ Por. http://www.catholic-hierarchy.org/diocese/dmndi.html [dostęp 2.10.2014]. 
Diecezja obejmuje obecnie 16 parafii, 28 terenów duszpasterskich i ponad 400 stacji misyjnych (outstations) ${ }^{3}$. Liczba tych ostatnich ciągle się zmienia ze względu na dynamicznie rozwijającą się sytuację w prowincji. Na miejsce wiosek zniszczonych podczas walk plemiennych powstają nowe, często dzielące między siebie mieszkańców poprzedniej wioski. Stopniowy wzrost populacji sprzyja również rozwijaniu się miasteczek i powstawaniu nowych osad, zwłaszcza wzdłuż szlaków komunikacyjnych. Liczba katolików jest trudna do oszacowania. Na podstawie zapisów ksiąg metrykalnych można stwierdzić, że jedna trzecia populacji Southern Highlands przynależy do Kościoła katolickiego ${ }^{4}$, ale i ta sytuacja jest płynna $\mathrm{z}$ uwagi na coraz częstsze migracje ludności oraz swoisty eklektyzm religijny, któremu sprzyja brak wyrazistych różnic pomiędzy Kościołami protestanckimi oraz rozwijającymi się sektami.

Diecezja Mendi jest silnie zróżnicowana kulturowo i językowo. Historycznie mieszkańcy Papui-Nowej Gwinei nigdy nie wytworzyli jednej struktury państwowej, a wielość języków dodatkowo utrudniała budowanie systemu społecznego opartego na wspólnocie kulturowej i wymianie handlowej. Nawet współcześnie trudno taką wspólnotę osiągnąć. Ta różnorodność jest największym bogactwem kraju, ale zarazem jego największym wyzwaniem. Według D. Robie ludność Papui-Nowej Gwinei posługuje się 867 językami plemiennymi i trzema językami oficjalnymi: angielskim, tok pisin (pidgin) oraz motu $^{5}$. Języki oficjalne nie mają źródeł $\mathrm{w}$ tradycji plemiennej i zostały upowszechnione dzięki pracy misjonarzy i niemiecko-australijskim wpływom ekonomicznym. Plemienna kultura pozostaje głównym znakiem tożsamości i przynależności do konkretnej wspólnoty. Nie zmieniło tego nawet uzyskanie przez Papuę-Nową Gwineę niepodległości w 1975 r. System plemienny był znacznie silniejszy i bardziej rozbudowany niż tworzący się system państwowy. W konsekwencji w Papui-Nowej Gwinei zaczęły funkcjonować dwa różne systemy, jeden oparty na prawie państwowym, a drugi na prawie plemiennym. Obydwa stykały się ze sobą i przeplatały, lecz nigdy nie doszło do ich połączenia. Tak więc oficjalnie obowiązuje prawo stanowione przez rząd, nieoficjalnie zaś sprawy konfliktowe rozwiązywane są na drodze walk plemiennych. $\mathrm{Na}$ obszarze Southern Highlands sytuacja jest jeszcze bardziej skomplikowana, ponieważ wiele plemion zasiedla tereny górzyste, co tym bardziej izoluje je od

\footnotetext{
${ }^{3}$ Outstation to wspólna nazwa dla kaplic i innych miejsc kultu, w których wierni gromadzą się na sprawowanie sakramentów oraz katechizację. Nie są to osobne jednostki administracyjne, ale stanowią centra duszpasterskie dla pojedynczej wioski lub kilku wiosek.

${ }^{4}$ Dokładna liczba mieszkańców prowincji Southern Highlands jest nieznana. Według statystyk lokalnego biura Justice and Peace w 2002 r. w prowincji mieszkało około 544 tys. osób. Dla roku 2004 podano liczbę 546400 .

${ }^{5}$ Por. D. Robie, Tongue-tied in PNG, „Papua New Guinea Post-Courier”, 8.04.1994, s. 31.
} 
reszty kraju. Rosnące napięcia pomiędzy plemionami oraz olbrzymia korupcja stały się powodem licznych wojen i bezprawia ${ }^{6}$.

Za początek szczególnej eskalacji przemocy na terenie Southern Highlands uważa się początek lat dziewięćdziesiątych zeszłego stulecia. Defraudacja pieniędzy pochodzących $\mathrm{z}$ prowincji, oszustwa w wyborach parlamentarnych, brak konkretnej reakcji na przemoc ze strony służb policyjnych i wojskowych doprowadziły do niekontrolowanych walk i napadów, a w konsekwencji do bezkarnego zabijania niewinnych ludzi. Smutne jest to, że nierzadko sama policja była odpowiedzialna za przemoc lub wspierała jedną ze stron konfliktu. Na skutek tych wydarzeń w 1996 r. władze kościelne diecezji Mendi postanowiły otworzyć specjalne biuro do spraw pokoju i pojednania pomiędzy plemionami - Jucstice, Peace and Development Office, częściej określane jako Diocesan Development Secretariat (DDS) - Diecezjalny Sekretariat ds. Rozwoju (dalej: Sekretariat) ${ }^{7}$.

\section{Początki działalności Diecezjalnego Sekretariatu ds. Rozwoju}

Głównym pomysłodawcą i inspiratorem idei utworzenia Sekretariatu był ówczesny biskup diecezji Mendi, Stephen Reichert OFM Cap. Jako młody misjonarz przybył do Papui-Nowej Gwinei w lipcu 1970 r. ${ }^{8}$ i rozpoczął pracę duszpasterską w Southern Highlands w miejscowości Det. Później jako superior kapucynów w Papui-Nowej Gwinei miał okazję dokładnie poznać diecezję z jej licznymi problemami, wynikającymi nie tylko z różnic kulturowych, ale również $\mathrm{z}$ szybkich przemian społecznych zachodzących $\mathrm{w}$ wioskach i miasteczkach. W obliczu skomplikowanej sytuacji społeczno-kulturowej i rosnącej fali przemocy (w walkach zaczęto używać m.in. broni maszynowej) bp S. Reichert zasugerował zaangażowanie osób trzecich, czyli mediatorów, którzy potrafiliby zachować bezstronność oraz skłonić strony konfliktu do dialogu?

Wzrost przemocy, zwłaszcza wzdłuż dróg publicznych, np. na odcinku Det-Tari, miał fatalne skutki dla bezpieczeństwa podróży i sytuacji ekonomicznej wiosek położonych w znacznej odległości od miast. Zaczęło brakować pod-

\footnotetext{
${ }^{6}$ Brakuje bezpośrednich zapisów o liczbie oraz czasie trwania konfliktów zbrojnych w diecezji Mendi. Z informacji uzyskanych bezpośrednio od abp. Stephena Reicherta, który jeszcze jako biskup diecezji Mendi był zaangażowany w działania pojednawcze pomiędzy plemionami, wynika, że liczba konfliktów była stosunkowo wysoka, lecz trudna do ustalenia.

${ }^{7}$ Nazwa Diocesan Development Secretariat została wprowadzona w celu podkreślenia integralności działań tej organizacji z Planem Pastoralnym Diecezji Mendi.

${ }^{8}$ Wywiad $\mathrm{z}$ abpem S. Reichertem, materiały w posiadaniu autora.

${ }^{9}$ Tamże.
} 
stawowych lekarstw i opieki medycznej. Nie wiadomo nawet, ile broni palnej było w posiadaniu lokalnych plemion w $1996 \mathrm{r}$. Pierwsze szczegółowe badania na ten temat zostały przeprowadzone dopiero w 2004 r. ${ }^{10}$ przez profesora Philipa Alpersa z Uniwersytetu w Sydney ${ }^{11}$. Wynika z nich, że lokalna policja nie prowadziła rejestru broni, którą posługiwała się miejscowa ludność. Według administratora dystryktu Tari, Philipa Moya, na terenie Southern Highlands wykorzystywana była $\mathrm{w}$ większości broń palna domowej produkcji ${ }^{12}$, aczkolwiek według ministra do spraw wewnątrzrządowych, Sir Petera Bartera, liczba broni palnej seryjnej produkcji mogła być znacznie wyższa, niż wcześniej przypuszczano $^{13}$. Jedno jest pewne, że z 2400 karabinów M-16 dostarczonych do sił zbrojnych Papui-Nowej Gwinei w latach osiemdziesiątych i dziewięćdziesiątych ubiegłego stulecia tylko 43-45 \% było ciągle w posiadaniu armii ${ }^{14}$. Ponad 55\% broni dostało się do rąk cywilów drogą nielegalnej sprzedaży bądź kradzieży.

W takiej sytuacji niezbędne było włączenie się Kościoła w proces pojednania pomiędzy plemionami. Sekretariat od samego początku czynnie angażował się w budowanie porozumienia i łagodzenie napiętej sytuacji. Celem tej instytucji była pomoc w budowaniu systemu integralnego rozwoju społeczeństwa ${ }^{15}$. Członkowie Sekretariatu dostrzegali potrzebę wyzwolenia ludzi ze strachu przed innymi oraz wsparcia ich wysiłków ukierunkowanych na obronę własnej godności. Cele i zadania były bardzo szczytne, ale ich realizacja wymagała dużych nakładów finansowych. Do realizacji projektów Sekretariat w ciągu sześciu lat pozyskał ponad milion kina (w 1975 r. ta waluta zastąpiła australijskiego dolara) ${ }^{16}$. Dzięki wsparciu diecezji Mendi i zaufaniu, jakim cieszy się Kościół katolicki w państwie, fundusze te zostały przekazane bezpośrednio do diecezji Mendi, z pominięciem lokalnych władz cywilnych. Pieniądze te przeznaczono na różnego rodzaju programy edukacyjne, których celem było przełamanie stereotypów myślenia plemiennego i otwarcie się na inne kultury. Członkowie biura włączali się czynnie w łagodzenie konfliktów, często ryzykując własne życie. Wśród najważniejszych inicjatyw pokojowych

${ }^{10}$ Informacje sprzed 2004 r. zawierają wiele nieścisłości i często nie odnoszą się do faktycznego stanu.

${ }^{11}$ Badania te zostały opublikowane w 2005 r. na zlecenie Graduate Institute of International Studies w Genewie w ramach projektu „The Small Arms Survey”. Por. P. Alpers, Gun-Running in Papua New Guinea: from arrows to assault weapons in the Southern Highlands, A publication of the Small Arms Survey, http://www.smallarmssurvey.org/fileadmin/docs/C-Special-reports/SASSR05-Papua-New-Guinea.pdf [dostęp 2.10.2014].

12 Tamże, s. 37.

${ }^{13}$ Tamże.

${ }^{14}$ Por. tamże, s. 38.

${ }^{15}$ Por. R. Ton, Report from 1996-2002, Diocesan Development Secretariat, Mendi 2002, s. 4.

${ }^{16}$ Por. tamże, s. 4. 
można wskazać negocjacje dotyczące zakończenia walk pomiędzy plemionami Det i Poroma, Humsem i Kundup-Konjop, Pingrip (wraz z Sengso) i Komea, Uma (wraz z Sumie) i Kagua, Pombereal i Utupia. Równolegle do tych wysiłków mediacyjnych Sekretariat zajmował się również drobniejszymi konfliktami pomiędzy rodzinami w plemionach.

Jednym z najbardziej aktywnych działaczy był Raymond Ton, który jako dyrektor Sekretariatu uczestniczył również czynnie w rozwiązywaniu najtrudniejszych przypadków ${ }^{17}$. Dzięki jego działalności udało się załagodzić konflikt pomiędzy Det i Poroma, a on sam zdobył wielkie zaufanie w różnych plemionach.

Korzystając ze środków finansowych udzielanych przez diecezję Mendi oraz Caritas Papui-Nowej Gwinei, Raymond Ton mógł przemieszczać się po całej prowincji ze statusem negocjatora pokojowego (peacemaker) i swobodnie prowadzić rozmowy ze stronami w sporze ${ }^{18}$. Sięgając do tradycyjnych form pojednania międzyplemiennego, łagodził współczesne konflikty.

Lata dziewięćdziesiąte ubiegłego wieku były szczególnie trudnym okresem dla prowincji Southern Highlands. Przez dwa lata trwały nieprzerwanie walki pomiędzy plemionami i wioskami położonymi zwłaszcza wzdłuż drogi Mendi-Tari. Brak perspektywy zakończenia konfliktów oraz napady i rozbój dotknęły bardzo mocno diecezję Mendi, tak od strony ekonomicznej, jak i duchowej. Ponieważ misjonarze nie mogli bezpiecznie przemieszczać się pomiędzy stacjami misyjnymi, małe wspólnoty katolików cierpiały z powodu braku posługi sakramentalnej i możliwości uczestniczenia we Mszy Świętej. Pojazdy misjonarzy stawały się często celem napadów i źródłem potencjalnych zysków. W tym czasie okradziono np. większość transportów żywności i lekarstw przeznaczonych dla katolickiej szkoły średniej w Tari ${ }^{19}$.

Działania rządu Papui-Nowej Gwinei na rzecz złagodzenia sytuacji w prowincji Southern Highlands były znikome i nie przynosiły żadnego skutku. Lokalna ludność nie ufała wysiłkom rządu, który był dla wielu bardziej symbolem skorumpowania niż nadziei. Jedyną instytucją, która ciągle cieszyła się zaufaniem, był Kościół katolicki. Diecezjalny Sekretariat ds. Rozwoju czynnie zaangażował się w budowanie porozumienia. Jego członkowie czuli się wewnętrznie odpowiedzialni za wprowadzenie pokoju pomiędzy plemionami, z których często sami pochodzili. Przy pełnym poparciu ze strony bp. Reicherta oraz misjonarzy pracujących w diecezji Mendi mediatorzy udawali się na rozmowy do poszczególnych wiosek i grup partycypujących w konfliktach. Również sam biskup często przybywał na miejsce spotkań i brał udział w roz-

\footnotetext{
${ }^{17}$ Wywiad z Raymondem Tonem, materiały w posiadaniu autora.

18 Tamże.

19 Tamże.
} 
mowach stron zaangażowanych w walki ${ }^{20}$. Przedłużeniem i dopełnieniem tych wysiłków była praca specjalnej grupy działającej w ramach Sekretariatu, zwanej Grupą Sprawiedliwości i Pokoju (Justice and Peace Group).

\section{Bezpośrednie negocjacje pokojowe prowadzone przez Grupę Sprawiedliwości i Pokoju}

Mówiąc o działalności Grupy Sprawiedliwości i Pokoju (Justice and Peace Group) trzeba pamiętać, że była ona niejako ukoronowaniem wysiłków podejmowanych na rzecz pokoju przez misjonarzy-kapucynów, władze diecezji oraz Sekretariat. Każdy element tej współpracy opierał się na charyzmacie poszczególnych grup. Kapucyni, którzy w tym czasie stanowili większość misjonarzy w diecezji Mendi, starali się dotrzeć do ludzi drogą wiary, z otwartością i współczuciem. Zachęcali całe wspólnoty do wytrwałej modlitwy o pokój, współtowarzyszyli pokrzywdzonym poprzez niesienie pomocy duchowej. Na duchowo przygotowany grunt przybywali reprezentanci Sekretariatu należący do Grupy Sprawiedliwości i Pokoju jako negocjatorzy podczas rozmów pomiędzy zwaśnionymi stronami. Rozmowy zaczynały się od rozpoznania kluczowych osób, które miały największy wpływ na pozostałych mieszkańców danej wioski. Bardzo często były to osoby młode, silne i pełne energii, zdolne do zdecydowanej walki. Nawiązanie z nimi kontaktu i zdobycie ich zaufania stanowiło pierwszy krok w bezpośrednich działaniach pokojowych. Wszelkie procesy rehabilitacji stron odbywały się przy ich udziale i akceptacji. Oficjalnie decyzje pokojowe były podejmowane przez liderów rodzin poszczególnych plemion, lecz nieoficjalnie to właśnie młodzi ludzie stanowili źródło konfliktów i to właśnie ich trzeba było przekonać do powstrzymania się od dalszej przemocy. Dzięki poparciu ze strony starszych mieszkańców wiosek oraz przykładowi, który płynął ze strony Kościoła, w wielu przypadkach udało się przekonać walczących członków plemion do uznania bezsensowności dalszej walki. Niestety, takie dyskusje i spotkania czasami kończyły się przetrzymywaniem członków Grupy Sprawiedliwości i Pokoju, a w kilku wypadkach nawet atakiem na katolickich misjonarzy i współpracujące z nimi osoby świeckie ${ }^{21}$.

Dialog prowadzony w wioskach poszczególnych plemion miał drugi poziom, w który zaangażowani byli już sami liderzy plemion. Miał on uświa-

${ }^{20}$ Wywiad z abpem S. Reichertem, dz. cyt.

${ }^{21}$ Według relacji Raymonda Tona w latach 1996-1998 liczba napadów rabunkowych na pojazdy misyjne wynosiła średnio około dwóch w ciągu tygodnia. Nie wszystkie jednak kończyły się kradzieżami produktów transportowanych przez misjonarzy. Wywiad z Raymondem Tonem, dz. cyt. 
domić, że to, co młodzi ludzie uważali za swą siłę, tak naprawdę stanowiło o słabości plemienia i w konsekwencji obracało się przeciwko miejscowej ludności ${ }^{22}$. Ludzie posiadali pieniądze, ale nie mogli ich użyć ze względu na brak towarów. Dzieci nie mogły podjąć edukacji z powodu zamknięcia szkół lub całkowitego ich zniszczenia. Ludzie chorzy umierali z braku lekarstw i pomocy medycznej. Takie przedstawienie faktów często sprawiało, że liderzy walk zaczynali szukać rozwiązań prowadzących do zakończenia konfliktu ${ }^{23}$.

W przywracanie pokoju zaangażowanych było wiele kobiet, zwłaszcza należących do grupy Legionów Maryi. Jako matki i żony starały się wywierać nacisk na mężczyzn, aby zaniechali dalszych walk. Organizowały się w grupy modlitewne, zapraszając do współpracy również członków wspólnot protestanckich $^{24}$. Ta rosnąca w siłę akcja powoli zaczęła przynosić owoce, zwłaszcza w wioskach położonych w buszu.

Prace na rzecz wprowadzenia pokoju były torpedowane również przez policję, która będąc niekiedy bezpośrednio zaangażowana w konflikt, starała się utrudniać wysiłki podejmowane przez katolickie organizacje. Raymond Ton $\mathrm{w}$ trakcie wykonywania pracy mediatora był kilkakrotnie zatrzymywany przez policję i rewidowany pod zarzutem dostarczania broni dla walczących grup. Dopiero interwencja bp. Stephena Reicherta doprowadziła do zaprzestania takich szykan ${ }^{25}$.

Kościół katolicki wspierał wszelkie działania pokojowe w prowincji Southern Highlands również logistycznie. Dzięki zaangażowaniu bp. Reicherta Diecezjalny Sekretariat ds. Rozwoju otrzymał samochód, miejsce do prowadzenia oficjalnego biura oraz finansowe wsparcie na pokrycie kosztów związanych z aktywnością Grupy Sprawiedliwości i Pokoju ${ }^{26}$. Dzięki wysokiej skuteczności działań Kościoła w konfliktach międzyplemiennych zyskał uznanie i zaufanie także rządu Australii, który rozpoczął bezpośrednią współpracę z diecezją Mendi, pomijając oficjalne relacje z rządem Papui-Nowej Gwinei.

Konflikt, który obejmował tereny Tari, Nipa, Margarima i Det, trwał z małymi przerwami ponad dziewięć lat. Na jego zakończenie Grupa Sprawiedliwości i Pokoju potrzebowała dwóch lat rozmów i porozumień, które sprawi-

${ }^{22}$ Przykładem dramatycznych konsekwencji walk może być misja w Sumi, która została całkowicie zniszczona podczas walk plemiennych, lub szkoła średnia w Mendi, której część dormitoriów została spalona w czasie walk przedwyborczych. W obydwu przypadkach strony walczące zniszczyły miejsca, które były dobrem wspólnym lokalnych społeczności.

${ }^{23}$ Wywiad z abpem S. Reichertem, dz. cyt.

${ }^{24}$ Grupa Sprawiedliwości i Pokoju bardzo często stykała się z małymi wspólnotami religijnymi, które same były zaangażowane w konflikty międzyplemienne. Działalność Legionów Maryi powoli przekonywała lokalne odłamy Kościołów protestanckich do zaprzestania wspierania walczących grup.

${ }^{25}$ Wywiad z Raymondem Tonem, dz. cyt.

${ }^{26}$ Wywiad z abpem S. Reichertem, dz. cyt. 
ły, że lokalna społeczność zmieniła swoje nastawienie do przemocy i pokoju. Całkowite zakończenie walk nastąpiło dopiero po roku 2004. Nie byłoby ono możliwe bez czynnego zaangażowania się Kościoła i jego pomocy świadczonej najbardziej pokrzywdzonym. Obok kapłanów i sióstr zakonnych w proces ten zaangażowane były 23 osoby świeckie, których prace koordynował Raymond Ton ${ }^{27}$.

\section{Dalsze programy i inicjatywy podejmowane przez Diecezjalny Sekretariatu ds. Rozwoju}

Działalność Diecezjalnego Sekretariatu ds. Rozwoju nie ograniczała się tylko do rozwiązywania konfliktów. Obejmowała ona również różnego rodzaju projekty społeczne, które miały przyczynić się do dalszego pokojowego współistnienia plemion oraz wzajemnej współpracy. Jeden z głównych projektów dotyczył pozyskiwania wody pitnej. Dzięki bliskiej współpracy z Caritas Papui-Nowej Gwinei udało się rozpocząć 17 projektów gromadzenia wody pitnej, a z czasem powiększyć je o następnych $15^{28}$. Do pierwszej fazy zaliczono następujące miejsca: Ialibu - trzy projekty, Tari - trzy projekty, Pangia - jeden projekt, Komo - jeden projekt, Pureni - jeden projekt, Karinj - dwa projekty, Kagua - trzy projekty, Kutubu - jeden projekt, Mendi - jeden projekt, Pombereal - jeden projekt. Łączna kwota przeznaczona na realizację pierwszej fazy projektów wynosiła prawie 200 tys. kina ${ }^{29}$.

W parze z rozbudową infrastruktury wiosek szły również działania edukacyjne. Z inicjatywy Diecezjalnego Sekretariatu ds. Rozwoju powstawały programy, które miały pomóc dostosować mentalność plemienną do nowej rzeczywistości. W ciągu pierwszych sześciu lat działalności przeprowadzono 24 kursy Integralnego Rozwoju Ludzkiego (Integral Human Development), 13 szkoleń dla liderów, pięć programów rehabilitacyjnych dla młodzieży. Największą popularnością cieszył się kurs Integralnego Rozwoju Ludzkiego ${ }^{30}$. Aby objąć jak największą grupę młodzieży, kursy przeprowadzano w głównych miejscowościach prowincji Southern Highlands. Do najważniejszych należały Mendi (Diocesan Pastoral Center), Mendi (Lutheran Church), Ialibu, Wakwak (United Church), Pangia (Pastoral Center), Pureni (Pastoral Center), Lai Valley, Lower Mendi, Upper Mendi, Det-Poroma, Kuare-Kagua oraz Pombereal. Diecezja Mendi w ciągu zaledwie czterech lat przeznaczyła na

\footnotetext{
${ }^{27}$ Por. R. Ton, Report from 1996-2002, dz. cyt., s. 34.

${ }^{28}$ Por. tamże, s. 7.

${ }^{29}$ Por. tamże, s. 28.

${ }^{30}$ Por. tamże, s. 7.
} 
te cele 80 tys. kina, przyczyniając się w ten sposób do wzrostu świadomości społecznej i zrozumienia podstawowych wartości ludzkich ${ }^{31}$. Najważniejsze idee kursu zostały zaczerpnięte $\mathrm{z}$ opracowań przygotowanych przez księdza Tony'ego Byrne'a $\mathrm{SSpS}^{32}$ oraz trzytomowej pracy zbiorowej pod redakcją Anne Hope i Sally Timmel ${ }^{33}$.

Inną grupę kursów stanowiły programy zmierzające do podniesienia poziomu edukacji, a zwłaszcza zmniejszenia procentu analfabetyzmu. $\mathrm{W}$ tym celu Sekretariat przygotował kurs pisania i czytania (literacy training), skupiony głównie na osobach w średnim wieku, które w przeszłości nie otrzymały żadnego wykształcenia. Kursy te uczyły języka pidgin (tok pisin), który jest jedynym wspólnym językiem wszystkich plemion na terenie Southern Highlands. Ze względu na dużą liczbę zainteresowanych kursy prowadzono w trzech miejscowościach: Tari, Mendi oraz Ialibu. Koszty pokryła całkowicie diecezja Mendi oraz Caritas Papui-Nowej Gwinei. Rocznie przeznaczano na ten cel ok. 12 tys. kina. Suma ta wystarczała na pokrycie kosztów edukacji oraz niezbędnych materiałów dla około 100 uczestników kursu ${ }^{34}$.

System plemienny wymagał zastosowania nowych narzędzi duszpasterskich i edukacyjnych. Zaistniała więc potrzeba wymiany doświadczeń i spostrzeżeń, które pomogłyby osiągnąć zamierzone cele. Poszczególne diecezje z obszaru Southern Highlands powołały do istnienia sekretariaty, które miały założenia podobne do Diecezjalnego Sekretariatu ds. Rozwoju diecezji Mendi. W diecezji Wabag była to grupa nazwana Gutpela Sindaun Commitee, w Kundiawa funkcjonował The Caritas, Justice, Peace and Development Office, w Mont Hagen był to The Caritas-Justice, Development and Peace Board, a w Goroce Justice and Peace Office ${ }^{35}$. Dzięki współpracy pomiędzy diecezjami Diecezjalny Sekretariat ds. Rozwoju wypracował program edukacji politycznej, który miał przygotować ludność do świadomej decyzji podczas wyborów parlamentarnych. Według danych zgromadzonych przez Sekretariat pod koniec lat dziewięćdziesiątych około $90 \%$ walk plemiennych związanych było z sytuacją przedwyborczą. Do największej eskalacji przemocy doszło w 1992 oraz 1997 r., kiedy to wybuchło 12 różnych wojen pustoszących wioski w Southern Highlands ${ }^{36}$. Ko-

${ }^{31}$ Tamże, s. 30.

32 Tony Byrne opublikował dwie publikacje poświęcone pracy społecznej: T. Byrne, Integral development, Lusaka 1983; tenże, Working for Justice and Peace, Lusaka 1988.

33 Obydwie autorki przygotowały opracowanie Training for Transformation opublikowane przez Practical Action Publishing w 1984 r.

${ }^{34}$ Por. R. Ton, Report from 1996-2002, dz. cyt., s. 30.

${ }^{35}$ Por. Z. Kruczek, Mission models employed throughout the history of the Catholic Church in Papua New Guinea, w: Cywilizacja i kultura: Wspótczesne problemy, red. J. Zimny, Stalowa Wola-Sandomierz 2007, s. 39.

${ }^{36}$ Por. R. Ton, Report from 1996-2002, dz. cyt., s. 8. 
lejne wybory w 2002 r. już nie były tak krwawe, lecz pokazały słabość systemu wyborczego oraz brak ufności wobec władz cywilnych ${ }^{37}$.

Edukację polityczną prowadzono na trzech poziomach: liderów plemion, młodzieży męskiej (najczęściej zaangażowanej w walki międzyplemienne) oraz mieszkańców wiosek uprawnionych do głosowania ${ }^{38}$. Jak wynika z raportu przeprowadzonego na rzecz Diecezjalnego Sekretariatu ds. Rozwoju, większość mieszkańców Southern Highlands nie miała koncepcji praw człowieka i praw konstytucyjnych i w wielu wypadkach domagała się swoich praw drogą przemocy. Prawdziwym wyzwaniem była zmiana mentalności z postawy „na kogo powinniśmy głosować” w postawę ,za jakimi wartościami powinniśmy głosować" 39 . Przedstawiciele Kościoła musieli bardzo ostrożnie wyjaśniać zagadnienia dotyczące demokracji, aby nie postrzegano ich jako rzeczników któregoś z kandydatów.

Obok edukacji politycznej rozwijano projekty dotyczące młodzieży. Największym problemem młodych ludzi było uzależnienie od marihuany, która w Papui-Nowej Gwinei ma swoje naturalne środowisko, oraz nadużywanie alkoholu. Według międzynarodowej organizacji monitorującej używanie narkotyków (The International Narcotics Control Board), Australia i Papua-Nowa Gwinea zaliczane są do największych konsumentów marihuany ${ }^{40}$, choć niektórzy polemizują z tymi danymi ${ }^{41}$. Według ONZ marihuana jest dla wielu mieszkańców kraju głównym źródłem dochodów i zarazem źródłem powstawania przemocy w rodzinie i plemionach ${ }^{42}$. Z kolei Światowa Organizacja Zdrowia podaje niepokojące wyniki na temat spożycia alkoholu w Papui-Nowej Gwinei. Według statystyk średnia ilość spożytego czystego alkoholu wynosiła 2 litry na jednego mieszkańca w 1990 r. i od tego czasu systematycznie rośnie. W 2010 r. spożycie alkoholu wynosiło 2,5 litra. Zdaniem Diecezjalnego Sekretariatu ds. Rozwoju, jeszcze bardziej niepokojące jest, że ilość alkoholu na mieszkańca powyżej 15 roku życia wynosi 10,8 litra dla mężczyzn oraz 4,4 li-

${ }^{37}$ Według Blog of the Pacific Institute, rząd Papui Nowej Gwinei w 2002 r. przeznaczył na wybory 1,4 miliona dolarów amerykańskich, por. http://pacificinstitute.anu.edu.au/outrigger/2014/05/12/ pngs-elections-the-most-expensive-in-the-world-and-getting-worse/ [dostęp 12.05.2014]. Podczas nowej fali przemocy zniszczeniu uległo wiele szkół i lokalnych punktów pomocy medycznej.

${ }^{38}$ Por. R. Ton, Report from 1996-2002, dz. cyt., s. 9.

${ }^{39}$ Osoby zaangażowane w kursy przed wyborami do parlamentu nie mogły podawać imion kandydatów. Ich zadaniem było przekonać ludzi, że najważniejsze są wartości, które będzie reprezentował ich kandydat. Por. R. Ton, Report from 1996-2002, dz. cyt., s. 9.

${ }^{40}$ Por. International Narcotics Control Board, Report of the International Narcotics Control Board for 1997, United Nations, New York 1998.

${ }^{41}$ Por. D. McDonald, Cannabis in Papua New Guinea, http://www.pngaa.net/Library/Cannabis.htm._[dostęp 22.05.2014].

${ }^{42}$ United Nations, The empowerment of rural women and their role in poverty and hunger eradication, development and current challenges, New York 2012, http://www.un.org/womenwatch/ daw/csw/csw56/panels/panel2-Lilly-Be-Soer.pdf,_[dostęp 23.02.2012]. 
tra dla kobiet ${ }^{43}$. Nadużywanie alkoholu prowadzi bowiem do wielu wypadków na drogach, przemocy w rodzinie oraz gwałtów ${ }^{44}$.

Pracownicy Diecezjalnego Sekretariatu ds. Rozwoju, dostrzegając niebezpieczeństwa wynikające z bezkrytycznego korzystania z narkotyków i alkoholu, stworzyli program mający na celu uświadomienie młodym ludziom zgubne działanie środków odurzających (narkotyków i alkoholu) oraz ich bezpośredni wpływ na przemoc. W tym celu przeprowadzono wiele warsztatów i spotkań dla młodzieży i dorosłych ${ }^{45}$, począwszy od wiosek położonych w buszu, poprzez szkoły katolickie i niekatolickie, kończąc na miejscowych targowiskach. Trudno ocenić poziom skuteczności takich wysiłków. Według Raymonda Tona narkotyki wciąż są głównym problemem wielu grup społecznych i są źródłem przemocy w plemionach i poza nimi, dlatego niezbędne jest zdecydowane działanie Kościoła katolickiego w wioskach i małych grupach społecznych ${ }^{46}$.

\section{Podsumowanie}

Obecność Kościoła katolickiego w prowincji Southern Highlands nie ogranicza się tylko do podstawowych działań ewangelizacyjnych, skupionych wokół katechezy, głoszenia kerygmatu i udzielania sakramentów. Dzięki zaangażowaniu abp. Stephena Reicherta oraz wielu misjonarzy i ludzi świeckich do zwaśnionych plemion dotarła idea pokoju i współpracy. Wraz ze wzrostem siły oddziaływania świata zachodniego potrzebne było stworzenie mechanizmów do samoobrony przed utratą własnej kultury oraz w celu dokonywania selekcji pomiędzy pozytywnymi i negatywnymi elementami obcych kultur. Planowe działania na rzecz łagodzenia napięć i nieporozumień stopniowo zdobywały posłuch zwłaszcza młodszego pokolenia, pozostawiając ślady w społecznej mentalności. Ponieważ ,świadomość narodowa” dla mieszkańców Southern Highlands jest swoistą abstrakcją, przejście od myślenia kategoriami „moje plemię” do myślenia kategorią „mój kraj” jest wciąż bardzo odległą rzeczywistością. Ten powolny proces jest jednak niezbędny. W obliczu utraty

${ }^{43}$ Por. Papua New Guinea, Socioeconomic Context, Substance abuse, Papua New Guinea, pdf., http://search.who.int/search?q=alcohol+in+Papua + New + Guinea\&ie=utf8\&site=who\&client=_en r\&proxystylesheet=_en_r\&output=xml_no_dtd\&oe=utf8\&getfields=doctype, [dostęp 14.05.2014].

${ }^{44} \mathrm{Z}$ moich naocznych doświadczeń wynika, że młodzież mieszkająca na obrzeżach miast i w okolicznych wioskach bardzo często korzysta z marihuany i alkoholu. Brak pracy, centrów młodzieżowych oraz regularnych kontaktów z tradycyjnym miejscem pochodzenia w przypadku migrantów do większych skupisk ludności czyni nowo przybyłych mieszkańców miast „osobami znikąd”, czyli ludźmi bez korzeni. Szukając akceptacji środowiska, często wiążą się z grupami przestępczymi lub ludźmi będącymi w podobnej sytuacji.

${ }^{45}$ Wywiad z Raymondem Tonem, dz. cyt.

${ }^{46}$ Tamże. 
tradycyjnych wartości, rosnących wpływów cywilizacji zachodniej oraz chaosu wywołanego korupcją, Kościół katolicki stara się pełnić misję pojednania i pokoju. Sukcesy szeregu działań w diecezji Mendi oraz pozytywne zmiany, które stają się coraz bardziej widoczne, dają nadzieję, że w bliskiej przyszłości Papua-Nowa Gwinea stanie się krajem bardziej zintegrowanym społecznie i kulturowo.

\section{THE PARTICIPATION OF THE CATHOLIC CHURCH \\ IN THE PEACE PROCESS AMONG THE TRIBES OF SOUTHERN HIGHLANDS PROVINCE IN THE DIOCESE OF MENDI, PAPUA NEW GUINEA}

\section{SUMMARY}

The author describes several social and peace-making initiatives which were undertaken in the last decades by the Catholic organizations active within the diocese of Mendi in Papua New Guinea. The country gained independence in 1975, but remained culturally diversified. The basic identity for most of the citizens is still related to the tribal level. Political conflicts, corruption, abuse of alcohol and narcotics resulted in the past decades in several outbursts of violence among tribes of the Southern Highlands Province. Since the central government was unable to answer this challenge, the Catholic organizations of the Mendi diocese became very much involved in the peacemaking process and other social initiatives. Activities of two Catholic organizations are described in more detail, namely the Diocesan Development Secretariat and the Justice and Peace Group, which have succeeded in mediations among several tribes.

Keywords: Papua New Guinea, diocese of Mendi, peace process, Justice and Peace, tribal cultures, arms trafficking

Słowa kluczowe: Papua-Nowa Gwinea, diecezja Mendi, działalność pokojowa, Sprawiedliwość i Pokój, kultury plemienne, handel bronią

\section{BIBLIOGRAFIA}

Alpers P., Gun-Running in Papua New Guinea: from arrows to assault weapons in the Southern Highlands, A publication of the Small Arms Survey, http://www.smallarmssurvey.org/filead$\mathrm{min} /$ docs/C-Special-reports/SAS-SR05-Papua-New-Guinea.pdf [dostęp 2.10.2014].

Byrne T., Integral development, Lusaka 1983.

Byrne T., Working for Justice and Peace, Lusaka 1988.

Dworecki T., Z kraju kamiennej siekiery, Warszawa 1975. 
Hope A., Timmel S., Training for Transformation, Rugby 1984.

http://pacificinstitute.anu.edu.au/outrigger/2014/05/12/pngs-elections-the-most-expensive-in-theworld-and-getting-worse/ [dostęp 12.05.2014].

http://www.catholic-hierarchy.org/diocese/dmndi.html [dostęp 2.10.2014].

International Narcotics Control Board, Report of the International Narcotics Control Board for 1997, United Nations, New York 1998.

Kruczek Z., Mission models employed throughout the history of the Catholic Church in Papua New Guinea, w: Cywilizacja i kultura: Wspótczesne problemy, red. J. Zimny, Stalowa Wola-Sandomierz 2007, s. 39.

McDonald D., Cannabis in Papua New Guinea, http://www.pngaa.net/Library/Cannabis.htm. [dostęp 22.05.2014].

Papua New Guinea, Socioeconomic Context, Substance abuse, Papua New Guinea, pdf., http://search. who.int $/$ search $q \mathrm{q}=$ alcohol + in + Papua + New + Guinea\&ie $=$ utf $8 \&$ site $=$ who\&client $=$ en $r \& p r o x y-$ stylesheet=_en_r\&output=xml_no_dtd\&oe $=$ utf8\&getfields=doctype, [dostęp 14.05.2014].

Robie D., Tongue-tied in PNG, „Papua New Guinea Post-Courier”, 8.04.1994, s. 31.

Ton R., Report from 1996-2002, Diocesan Development Secretariat, Mendi 2002.

Tyszkowski S., Program rozwoju kultury fizycznej w Papui Nowej Gwinei (Prowincja Southern Highlans) wedlug wskazań ONZ oraz projektów własnych, Gdańsk 2008.

United Nations, The empowerment of rural women and their role in poverty and hunger eradication, development and current challenges, New York 2012, http://www.un.org/womenwatch/ daw/csw/csw56/panels/

panel2-Lilly-Be-Soer.pdf, [dostęp 23.02.2012].

MAREK KRóL, kapłan diecezji pelplińskiej i misjonarz w Papui-Nowej Gwinei, doktorant Wydziału Teologicznego Uniwersytetu Kard. Stefana Wyszyńskiego w Warszawie. W latach 2003-2007 pracował w Papui-Nowej Gwinei, w diecezji Mendi. Obecnie prowadzi kwerendę w archiwach kapucynów prowincji Mid-America w Stanach Zjednoczonych, badając misyjne zaangażowanie kapucyńskich misjonarzy w Papui-Nowej Gwinei. 